\title{
PEMBUATAN APLIKASI AUDIENCE RESPONSE SYSTEM BERBASIS WEB DAN ANDROID
}

\author{
Albert Leonardo Pisa ${ }^{*}$, Henry Novianus Palit ${ }^{2}$, Justinus Andjarwirawan ${ }^{3}$ \\ Program Studi Teknik Informatika, Fakultas Teknologi Industri, Universitas Kristen Petra \\ Jl. Siwalankerto 121 - 131 Surabaya 60236 \\ Telp. (031) - 2983455, Fax. (031) - 8417658 \\ E-mail: albert.leo93@gmail.com, hnpalit@petra.ac.id,justin@petra.ac.id \\ * Penulis korespondensi
}

\begin{abstract}
Abstrak: Audience Response System banyak digunakan pada berbagai event acara baik sebagai media untuk mengumpulkan informasi, mengumpulkan data, dan mengetahui pendapat masyarakat umum terhadap suatu isu, topik, berita. Audience Response System juga dapat digunakan untuk mengetahui kepuasan client atau customer terhadap kualitas produk atau jasa. Sayangnya kebanyakan audience response system yang ada saat ini berupa perangkat fisik yaitu berupa sebuah remote yang dimana sangat terbatas penggunaannya. Seiring berkembangnya teknologi, masyarakat memiliki smartphone yang dapat melakukan berbagai hal. perangkat fisik tersebut dapat digantikan dengan aplikasi atau program yang dapat di-install di smartphone, sedangkan polling dibuat melalui website. Audience response system dalam penelitian ini dibangun di atas platform Node.js, PhoneGap, dengan menggunakan Socket.IO sebagai Javascript library WebSocket agar mendukung komunikasi data dua arah. Berdasarkan hasil pengujian, aplikasi ini dapat menjalankan fungsi login, membuat polling, mengikuti polling, melakukan voting, dan tingkat reliabilitas sistem adalah $93 \%$.
\end{abstract}

Kata kunci: Audience response system, voting, polling, website, android

\begin{abstract}
Audience Response Systems are widely used in various events as a media to gather information, to collect data, and to know the opinions of the general public towards particular issues, topics, news. Audience Response System can also be used to find out the client or customer satisfaction to the quality of products or services. Unfortunately most of the audience response systems that exist today are in the form of a physical (or remote) device which is severely limited in use. Along with the development of technology, almost all people have a smartphone to support their daily activities. The physical remote device called a clicker can be replaced with an application or program that can be installed on smartphones, while the polls are created through the website. In this research, the Audience response system was built using Node.js, PhoneGap platform, and the WebSocket Socket.IO as Javascript library to support bi-directional data communications. Based on testing result, this application can run properly all the functionalities that have been mentioned such as login to the system, create a poll, join a poll, and give a vote. The realiability of the system is $93 \%$.
\end{abstract}

Keywords: Audience response system, voting, polling, website, android

\section{PENDAHULUAN}

Saat ini sistem yang ada untuk mengolah hasil polling masih menggunakan cara tradisional, yaitu data dari partisipan dikumpulkan terlebih dahulu hingga mencapai batas yang telah ditentukan atau hingga batas waktu yang diberlakukan telah berakhir, baru kemudian data diolah untuk ditampilkan hasilnya dalam berbagai bentuk. Partisipan tidak dapat langsung mengetahui hasil polling secara realtime.

Sistem polling yang ada saat ini, masih menggunakan alat fisik untuk melakukan polling. Contohnya adalah salah satu acara televisi Mario Teguh Golden Ways, dan acara televisi korea I Am a Man (Naneun Namja Da). Alat tersebut berupa sebuah remote yang dilengkapi dengan tombol pilihan jawaban untuk responden. Dengan demikian pihak narasumber harus mengeluarkan biaya lebih untuk membeli alat tersebut, dan semakin banyak jumlah responden yang ditargetkan, semakin banyak pula alat yang mesti disediakan. Akibatnya, semakin banyak pula biaya yang akan dikeluarkan untuk membeli alat tersebut beserta dengan perangkat lunaknya. Hal ini tentu merupakan sebuah pemborosan.

Terdapat sebuah website yang cukup terkenal di internet, yang menyediakan jasa pembuatan polling gratis melalui website mereka, dengan berbagai fitur yang disediakan dengan alamat www.polleverywhere.com. Salah satu fitur yang paling ditonjolkan adalah pemanfaatan media SMS (Short Message Service) sebagai media penyebaran dan pengumpulan jawaban dari dan ke responden. Namun terdapat kelemahan dari sistem ini, yaitu untuk memberikan 
jawabannya responden harus rela mengeluarkan uang untuk membayar biaya SMS sesuai tarif biasa operator.

Terdapat sebuah solusi untuk berbagai masalah diatas, yakni dengan membuat sebuah aplikasi sistem polling yang real-time berbasis web dan Android. Responden dapat memberikan jawabannya melalui sebuah aplikasi sederhana yang dibuat untuk menggantikan peran remote, sehingga meminimalkan biaya yang digunakan untuk memfasilitasi sistem polling yang dibutuhkan.

\section{TINJAUAN PUSTAKA}

\section{Audience Response System}

Audience Response Systems (ARS) merupakan alternatif media pengumpulan data berupa perangkat sistem informasi untuk memberikan respon dalam bentuk data numerik maupun kategorik terhadap pertanyaan yang diajukan. Hasil data selanjutnya akan disajikan sebagai feedback dari responden atau partisipan. [5]

Penggunaan umum ARS adalah berupa alat kontrol yang berada di tangan hadirin dihubungkan dengan perangkat lunak. Pada saat yang sama halaman presentasi menampilkan pertanyaan serta beberapa pilihan jawaban. Hadirin dapat berpartisipasi dengan memilih jawaban yang mereka anggap benar dengan cara menekan tombol koresponden pada alat nirkabel individu yang mereka pegang. Kemudian jawaban mereka akan dikirimkan ke stasiun dasar atau penerima pesan yang juga terhubung dengan komputer presentator. Dalam beberapa waktu yang telah ditentukan, ketika semua hadirin telah memberikan jawabannya, sistem akan mengakhiri pemungutan suara untuk pertanyaan terkait dan merangkumnya sebagai hasil dari seluruh jawaban peserta di ruangan tersebut.

\section{Node.js}

Node.js adalah sebuah platform software yang dipakai untuk membangun aplikasi - aplikasi serverside yang fleksibel di sebuah network / jaringan. Node.js menggunakan JavaScript sebagai bahasa pemrograman dan dapat dengan mudah menghasilkan throughput / pemrosesan tingkat tinggi melalui nonblocking I/O. Node.js memiliki fitur built-in HTTP server library yang menjadikannya mampu menjadi sebuah web server tanpa bantuan perangkat lunak lainnya seperti Apache atau Nginx. [8]

Node.js pertama kali dibuat oleh Ryan Dahl pada tahun 2009 yang kemudian berkembang pesat di bawah lisensi Open Source MIT oleh sebuah perusahaan bernama Joyent Inc.
Pada hakekatnya Node.js dikembangkan berdasarkan teknologi Google V8 JavaScript engine serta berisi kompilasi script inti dan banyak modul siap pakai yang bermanfaat sehingga pengguna (dalam hal ini web pengembang) tidak perlu melakukan coding dan mendesain segalanya dari awal. [8]

\section{MongoDB}

Mongo DB merupakan database open-source yang berorientasi pada dokumen, atau yang lebih populer disebut "NoSQL (Not Only SQL)". MongoDB bukanlah database relasional berbasis tabel yang telah lazim dikenal seperti MySQL, namun berorientasi pada dokumen. MongoDB menyimpan data dalam format serupa dengan notasi JSON (Java Script Object Notation) yang disebut BSON (Binary JSON) karena selain menangani data teks, juga mampu untuk menyimpan data biner (binary). Berikut ini adalah terminologi dan konsep yang perlu anda tahu di MongoDB, untuk memudahkan anda, maka akan saya buat tabel perbandingan dengan konsep yang ada di SQL database. [2]

Untuk primary key, walaupun penamaan istilahnya sama, namun dalam sisi implementasi sangat berbeda. Primary key di RDBMS adalah kolom unik di tabel yang didefinisikan sendiri oleh user. MongoDB secara otomatis membuatkan primary key di field_id dan akan terisi secara otomatis.

Tabel 1. Tabel Perbedaan MongoDB dan MYSQL

\begin{tabular}{ll}
\hline Istilah RDBMS & Istilah Mongo \\
\hline database & database \\
table & collection \\
row & document or BSON document \\
column & field \\
index & index \\
table join & embedded document \\
primary key & primary key \\
\hline
\end{tabular}

npm.js

npm, adalah singkatan dari node package manager, yang mana merupakan sebuah online repository, untuk mempublikasikan dan mendistribusikan kode-kode Node.js dari sebuah proyek. Selain itu npm adalah sebuah command-line utility yang digunakan oleh pengembang, untuk berinteraksi dengan repository. Command-line juga biasa digunakan untuk instalasi, mengelola versi, dan manajemen dependensi paket-paket kode dari repository secara langsung. Kebanyakan library dan aplikasi yang terbuat dari Node.js dipublikasikan di npm. Namun sayangnya untuk mengunduh modul-modul yang ada di online repository, dibutuhkan akses internet. [8] 
Untuk menggunakan modul, pengembang harus mengimpor modul tersebut terlebih dahulu dengan fungsi seperti ini: var module $=$ require ('nama module') lalu variabel modul dapat digunakan pada file dimana anda mengimpor file tersebut.

\section{Express.js}

Express.js adalah web application framework Node.js yang paling sering digunakan dan paling populer diantara yang lain. Express.js memiliki keunggulan yaitu performa yang cepat karena source code yang minimalis dan didesain sedemikian rupa demi mendapatkan performa website yang baik. [3]

\section{Mongoose}

Mongoose adalah sebuah ODM (Object Data Modelling untuk MongoDB). Awamnya, Mongoose lah yang bertugas menjadi jembatan antara aplikasi dengan database, karena Mongoose memodelkan data dari aplikasi ke dalam collection-collection dan mendesain struktur document di dalamnya [2].

Untuk menggunakan Mongoose, pertama-tama pengembang harus membuat schema. Schema berperan untuk memetakan collection pada MongoDB dan mendesain document yang ada di dalamnya. Berikut adalah contoh schema berdasarkan website resminya http://mongoosejs.com/docs/guide.html:

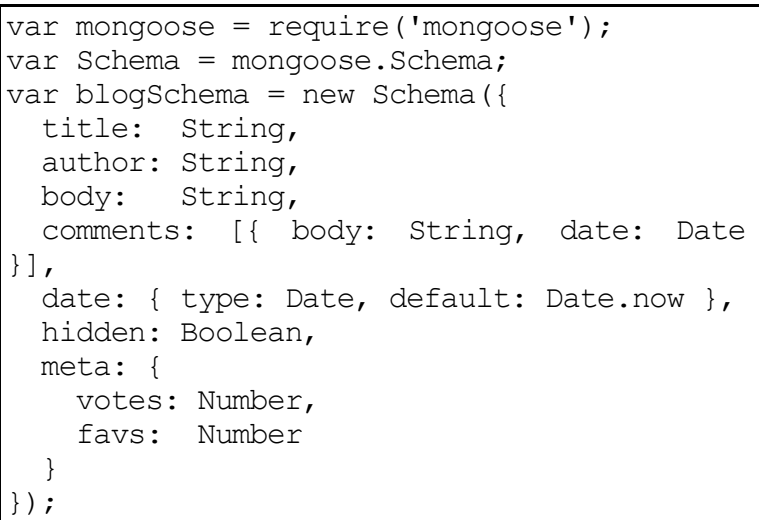

\section{Socket.IO}

Socket.IO merupakan JavaScript library untuk membuat website yang real-time, dan memungkinkan komunikasi dua arah yang real-time antara web client dan server. Memiliki 2 bagian library untuk clientside yang berjalan di browser dan server-side library untuk Node.js. berikut adalah cara menggunakan Socket.IO pada server Node.js. [10]

\section{PhoneGap}

PhoneGap adalah sebuah kerangka kerja/framework open source yang dipakai untuk membuat aplikasi cross-platform mobile dengan HTML5, CSS, dan JavaScript. PhoneGap menjadi suatu solusi yang ideal untuk seorang web developer yang tertarik dalam pembuatan aplikasi di smartphone. Dengan framework PhoneGap kita hanya perlu melakukan satu kali pemrograman dan dapat langsung di-compile ke semua platform sekaligus. [7]

\section{ANALISA DAN DESAIN SISTEM}

\section{Desain Sistem}

Skema desain sistem dan alur komunikasi data antar platform dapat dilihat pada Gambar 1. Website melakukan komunikasi dengan server melalui router, sedangkan dengan Android menggunakan Socket.IO. Sedangkan untuk mengakses database, baik Android maupun website harus melalui mongoose. Router, Socket.IO dan Mongoose semua merupakan bagian dari sebuah framework Node.js bernama Express.js.

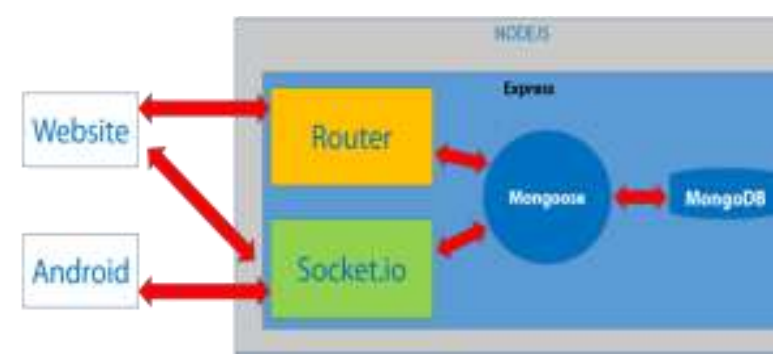

Gambar 1. Desain Sistem

\section{Desain Aplikasi}

Pada Gambar 2 adalah use case diagram sistem yang dibuat dalam penelitian ini. Seperti dapat dilihat pada gambar 2, bahwa pada aplikasi ini admin hanya dapat menggunakan fitur delete user, edit user, edit polling, delete polling pada website. Sedangkan user biasa dapat menggunakan fitur edit user, edit polling, delete polling, create polling, view polling, open polling, join polling, view event log, dan delete event log. Untuk masuk ke waiting room dan memulai polling (start polling), user terlebih dahulu harus memilih menu open polling. Sedangkan pada Android untuk bisa mengikuti polling dan melakukan vote, terlebih dahulu harus masuk ke waiting room, dan menunggu operator (user yang membuat polling) untuk memulai polling (start polling).

\section{Fungsi Search \& Join Polling}

Fungsi search \& join polling oleh user di Android menggunakan socket yang di-emit dari client menuju server, menggunakan parameter session key. Flowchart dari fungsi search \& join polling dapat dilihat pada Gambar 3. 


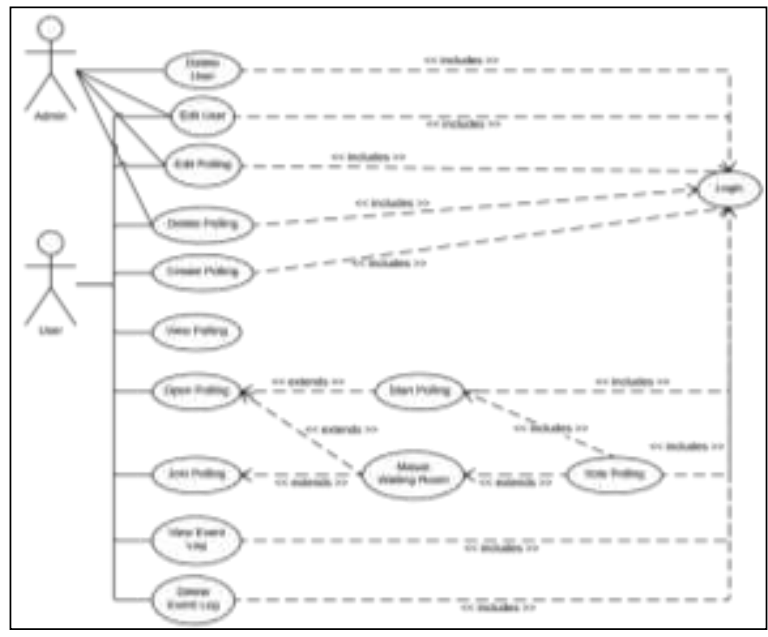

Gambar 2. Use Case Diagram Desain Aplikasi

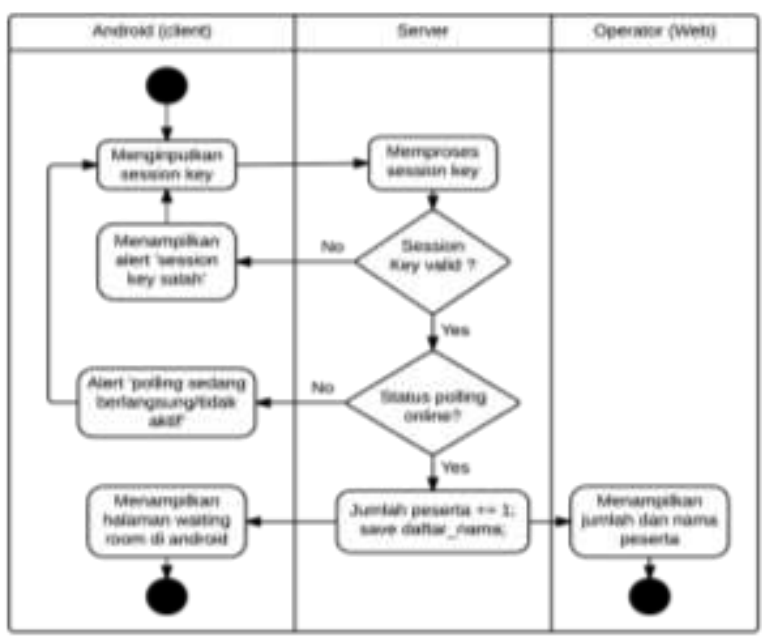

Gambar 3. Fungsi Search Polling

\section{Fungsi Leave Room}

Fungsi leave room oleh user di Android dijalankan ketika client menekan tombol back ataupun sign out di Android. Activity Diagram dari fungsi leave room dapat dilihat pada Gambar 4.

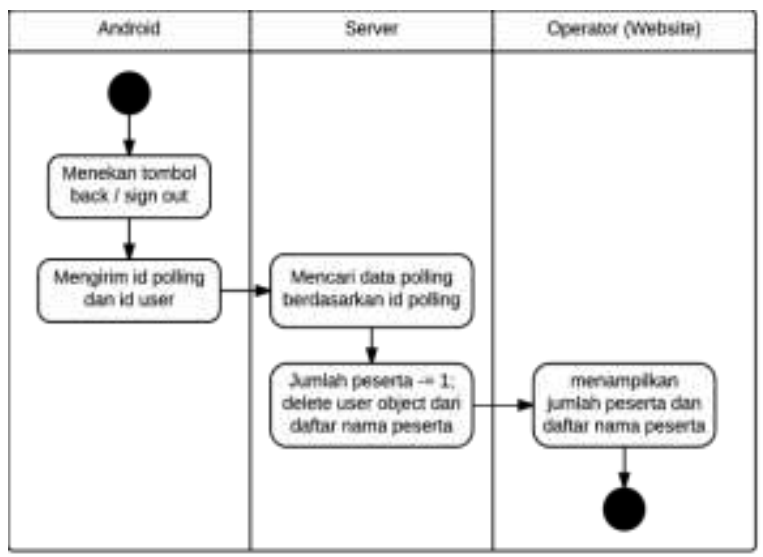

Gambar 4. Fungsi Leave Room

\section{Fungsi Open Polling}

Pada Gambar 5 adalah flowchart yang menampilkan proses yang terjadi saat operator di website menekan tombol open polling. ID polling dikirim sebagai parameter untuk mencari data polling yang ada, jika ditemukan maka selanjutnya server akan mengecek apakah polling tersebut telah memiliki session key atau belum, jika belum maka server akan men-generate session key secara acak, untuk kemudian dicek dengan session key dari polling lain, jika ada yang sama, maka akan dilakukan generate ulang, setelah itu server akan menampilkan halaman waiting room, beserta data berupa session key yang telah di-generate sebelumnya.

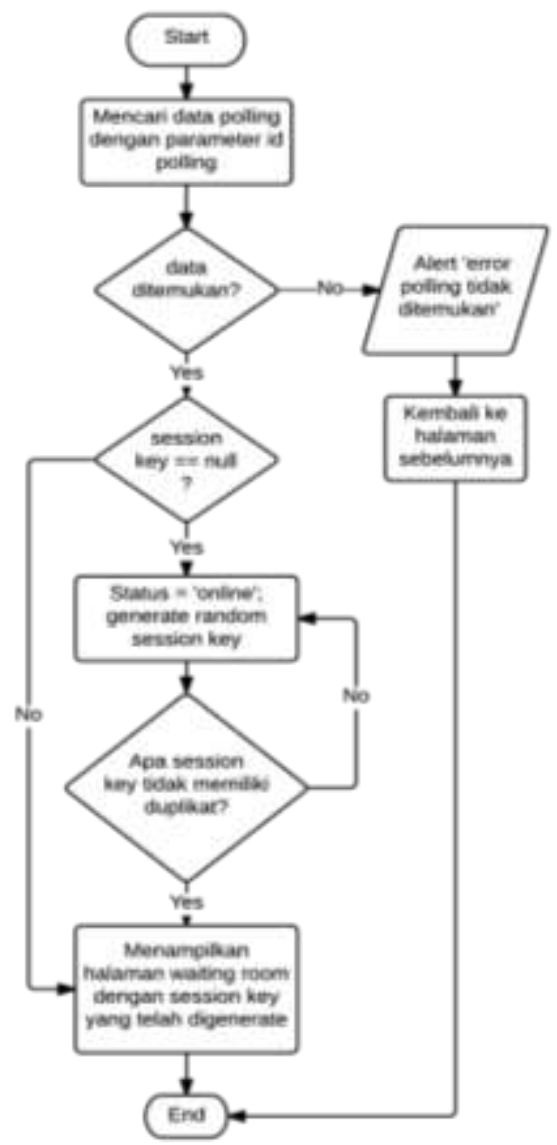

Gambar 5. Fungsi Open Polling

\section{Proses Sinkronisasi}

Pada Gambar 6 adalah Proses sinkronisasi dan voting antara operator dengan client. Proses sinkronisasi menggunakan socket yang di-emit dari operator di website menuju server, kemudian dilakukan query pada database untuk mencari data polling sesuai id polling dan index soal. Jika id polling valid, maka index soal dan data polling (soal dan pilihan jawaban) dikirimkan secara broadcast melalui socket, ke seluruh client (Android). 


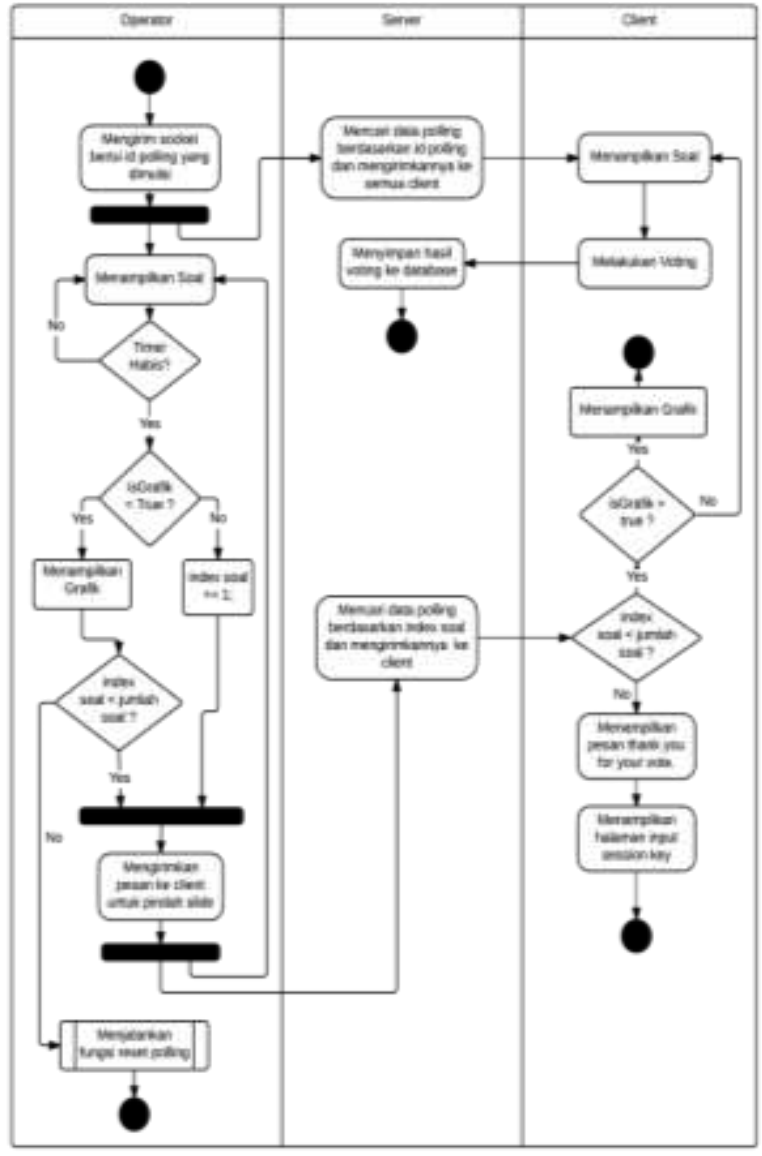

Gambar 6. Proses Sinkronisasi \& Voting

\section{Fungsi Reset Polling}

Pada 7 adalah fungsi reset polling. Fungsi ini dijalankan hanya setelah polling selesai dan operator menekan tombol finish. Fungsi ini berperan untuk menyalin semua data voting, jumlah peserta, daftar nama, dari tabel polling ke tabel $\log$ baru dan mereset tabel polling.

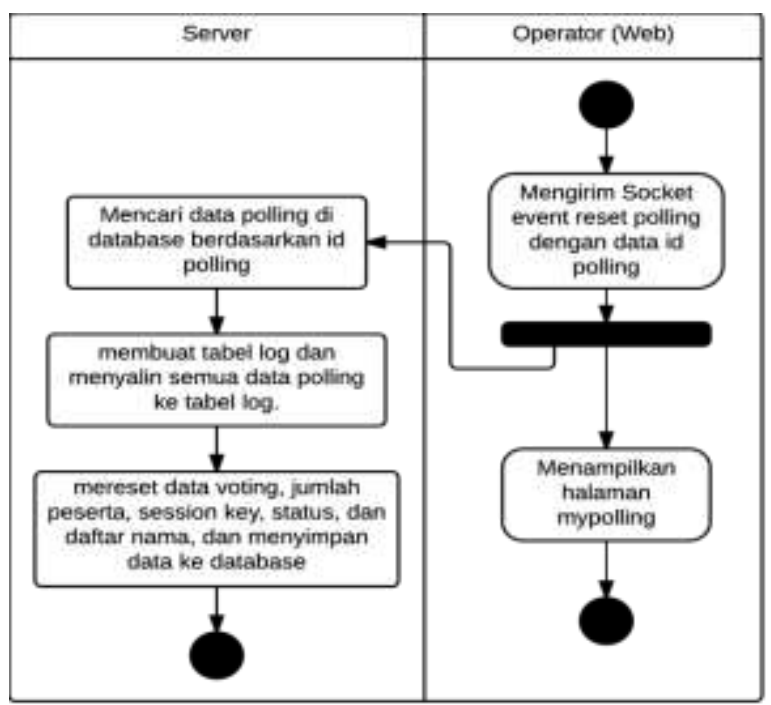

Gambar 7. Fungsi Reset Polling

\section{PENGUJIAN \& EVALUASI}

\section{Lingkungan pengujian}

Pengujian dilaksanakan menggunakan jaringan wifi speedy fiber optic dengan kecepatan 12 mbps. Semua memory RAM dan running apps device peserta juga telah dibersihkan terlebih dahulu untuk menghindari banyaknya komunikasi data yang berjalan di-system.

Pengujian dilakukan dengan menggunakan 15 smartphone yang berbeda, berikut ini adalah daftar spesifikasi smartphone yang digunakan dalam pengujian.

Tabel 2. Tabel daftar smartphone peserta dan spesifikasinya

\begin{tabular}{|c|c|c|c|c|}
\hline \multicolumn{2}{|c|}{ No Nama } & $\begin{array}{l}\text { Versi } \\
\text { Android }\end{array}$ & RAM & Processor \\
\hline 1 & Polytron W2430 & ICS & $512 \mathrm{MB}$ & Dualcore \\
\hline 2 & Samsung galaxy A5 & Lollipop & 2 GB & Quadcore \\
\hline 3 & $\begin{array}{l}\text { Samsung galaxy S4 } \\
\text { mini }\end{array}$ & Kitkat & $1,5 \mathrm{~GB}$ & Dualcore \\
\hline 4 & $\begin{array}{l}\text { Samsung Galaxy } \\
\text { Tab } 2 \text { (2 buah) }\end{array}$ & $\mathrm{JB}$ & $1 \mathrm{~GB}$ & Dualcore \\
\hline 5 & Oppo & Jelly bean & $1 \mathrm{~GB}$ & Dualcore \\
\hline 6 & Polytron & Jelly bean & $512 \mathrm{MB}$ & Dualcore \\
\hline 7 & $\begin{array}{l}\text { Lenovo A6000 ( } 2 \\
\text { buah) }\end{array}$ & Kitkat & $1 \mathrm{~GB}$ & Quadcore \\
\hline 8 & Lenovo A369i & Jelly bean & $512 \mathrm{MB}$ & Dualcore \\
\hline 9 & Evercoss A66A & Jelly bean & $1 \mathrm{~GB}$ & Quadcore \\
\hline 10 & Galaxy s3 mini & Jelly bean & $512 \mathrm{MB}$ & Dualcore \\
\hline 11 & Galaxy note 10.1 & Lollipop & $3 \mathrm{~GB}$ & Octacore \\
\hline & $\begin{array}{l}\text { Samsung galaxy } \\
\text { Grand } 2\end{array}$ & Kitkat & $1.5 \mathrm{~GB}$ & Quadcore \\
\hline & $\begin{array}{l}\text { Huawei Ascend } \\
\text { Mate } 7\end{array}$ & Lollipop & $2 \mathrm{~GB}$ & Octa core \\
\hline
\end{tabular}

Sedangkan untuk spesifikasi server (virtual machine) yang digunakan adalah sebagai berikut:

Prosesor: Intel Xeon CPU E5504 2Ghz

Jumlah Core: 2

Memori : 2GB

\section{Pengujian Sistem}

Gambar 8 menampilkan potongan halaman mypolling di website yang digunakan untuk menampilkan hasil polling yang telah dibuat sebelumnya oleh user.

Ujicoba 2

\section{POLLING MENU}

Gambar 8. Halaman Mypolling

Melalui halaman mypolling, pengguna dapat melihat polling yang telah dibuat dengan menekan tombol view, atau meng-edit dan menghapus polling dengan menekan tombol delete. 


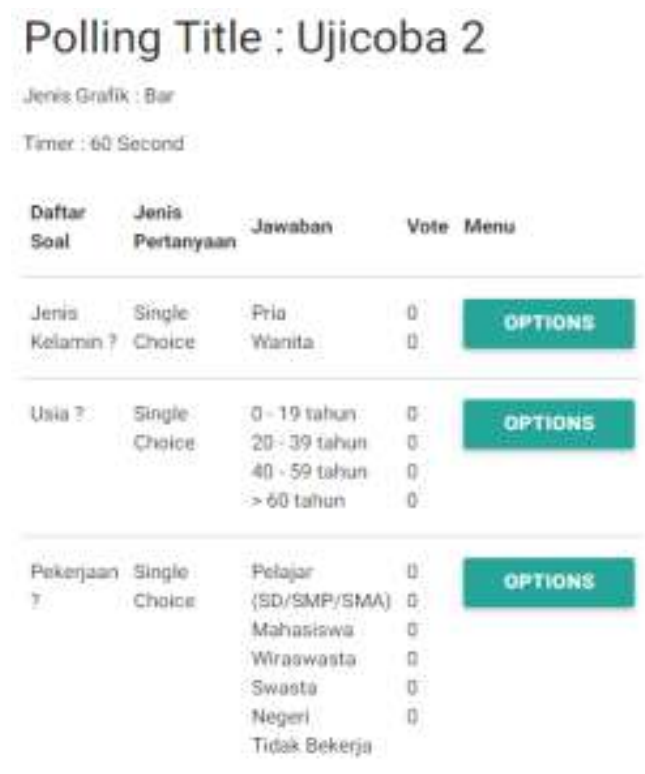

Gambar 9. Halaman View Polling

Halaman view pada Gambar 9 menampilkan berbagai detail polling yang telah dibuat mulai dari title, daftar soal, jenis pertanyaan, pilihan jawaban, timer, jenis grafik dan tombol delete. Baik timer maupun jenis grafik dapat diatur sebelumnya oleh pembuat polling. Minimum timer yang diperbolehkan adalah 5 detik, sedangkan maksimalnya 60 detik. Jenis grafik yang diperbolehkan adalah bar, column, dan pie chart.

\section{Ujicoba 2}

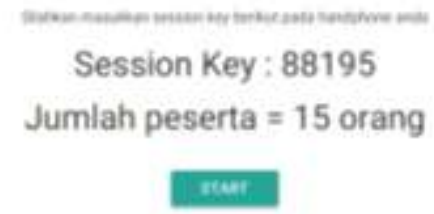

Gambar 10. Halaman Waiting Room Operator

Pada Gambar 10 adalah tampilan halaman waiting room pada website. pada halaman ini ditampilkan session key yang harus dimasukkan oleh peserta di Android untuk mengikuti polling seperti yang ditampilkan pada Gambar 13.

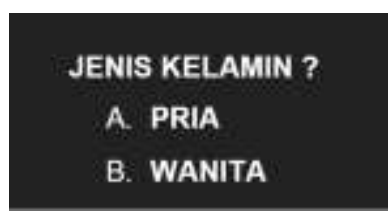

Gambar 11. Tampilan Halaman Operator

Sedangkan pada Gambar 11 adalah tampilan halaman operator di website saat polling dimulai. Setelah timer habis, maka ditampilkan grafik jumlah vote seperti pada Gambar 12.

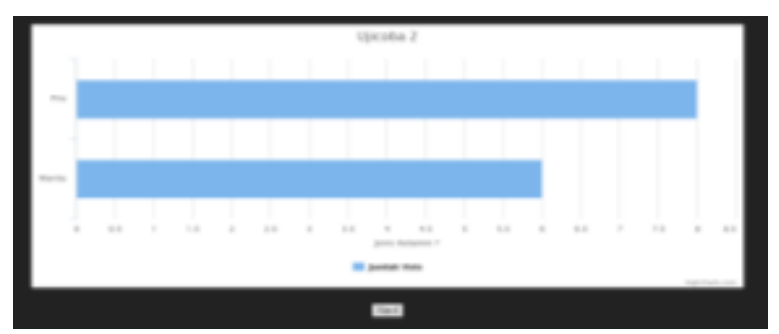

Gambar 12. Hasil Voting Pada Website

Pada aplikasi Android, halaman input session key akan ditampilkan setelah pengguna berhasil login atau register. Tampilan halaman input session key dapat dilihat pada Gambar 13.

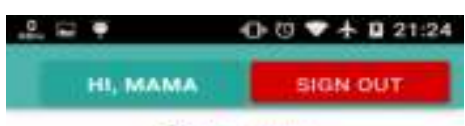

Server : andine

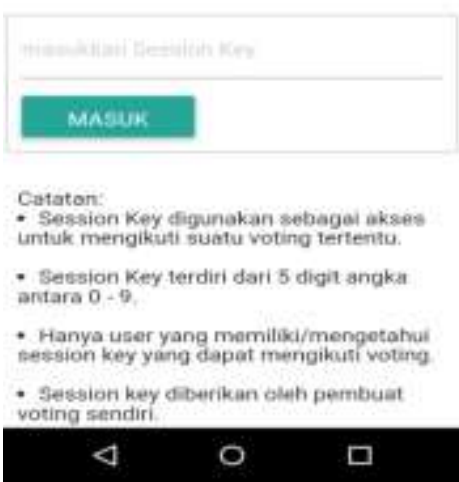

Gambar 13. Halaman Input Session Key

Jika session key yang di-input-kan user valid, maka halaman waiting room akan ditampilkan seperti pada Gambar 14.

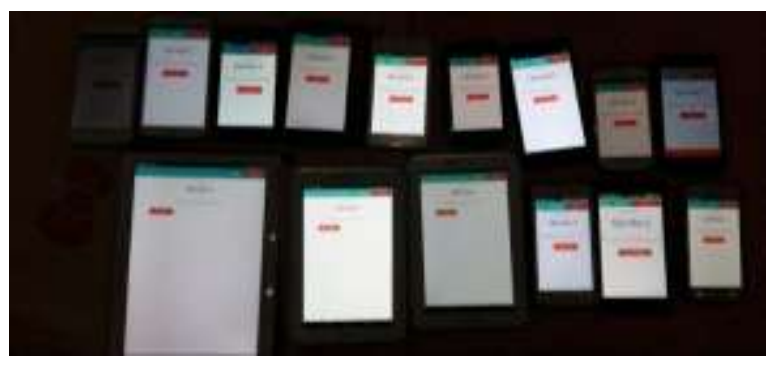

Gambar 14. Halaman Waiting Room Android

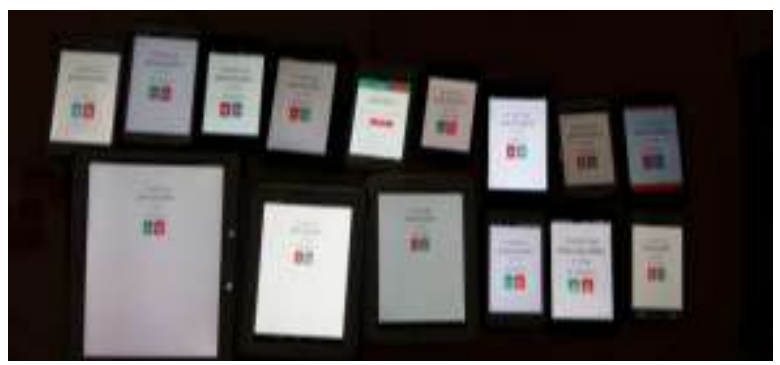

Gambar 15. Tampilan Voting di android 
Gambar 15 merupakan tampilan ketika responden melakukan vote pada suatu polling.

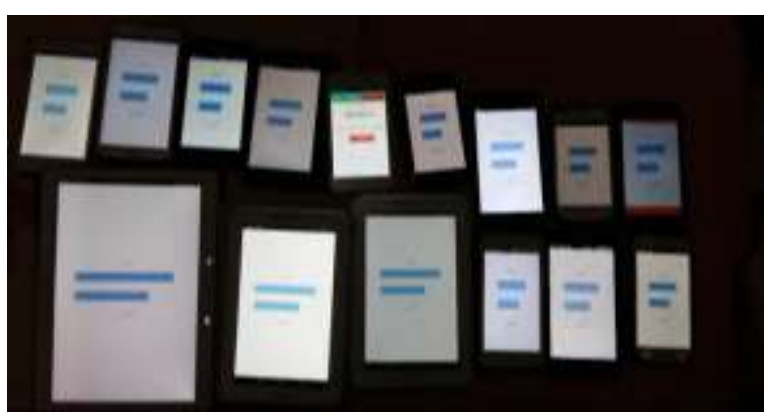

Gambar 16. Polling Chart

Pada Gambar 16, Chart akan ditampilkan seketika setelah timer habis.

\section{Evaluasi Hasil Pengujian}

Berdasarkan hasil pengujian, dari 15 peserta hanya 1 peserta yang gagal dalam mengikuti voting, yaitu device no 1 pada tabel 2, dikarenakan device peserta yang bersangkutan mengalami hang atau error, dan dari 14 peserta semua dapat melakukan voting, tidak ada yang gagal.

Gambar 17 adalah screenshot tampilan log saat peserta melakukan voting. Rata-rata waktu yang dibutuhkan bagi sistem untuk mengirimkan jawaban peserta ke server adalah <1 detik. Berdasarkan hasil pengujian, didapati tingkat reliabilitas sistem adalah 93\%, yang didapat dari jumlah peserta yang berhasil mengikuti voting/jumlah total peserta X $100 \%$.

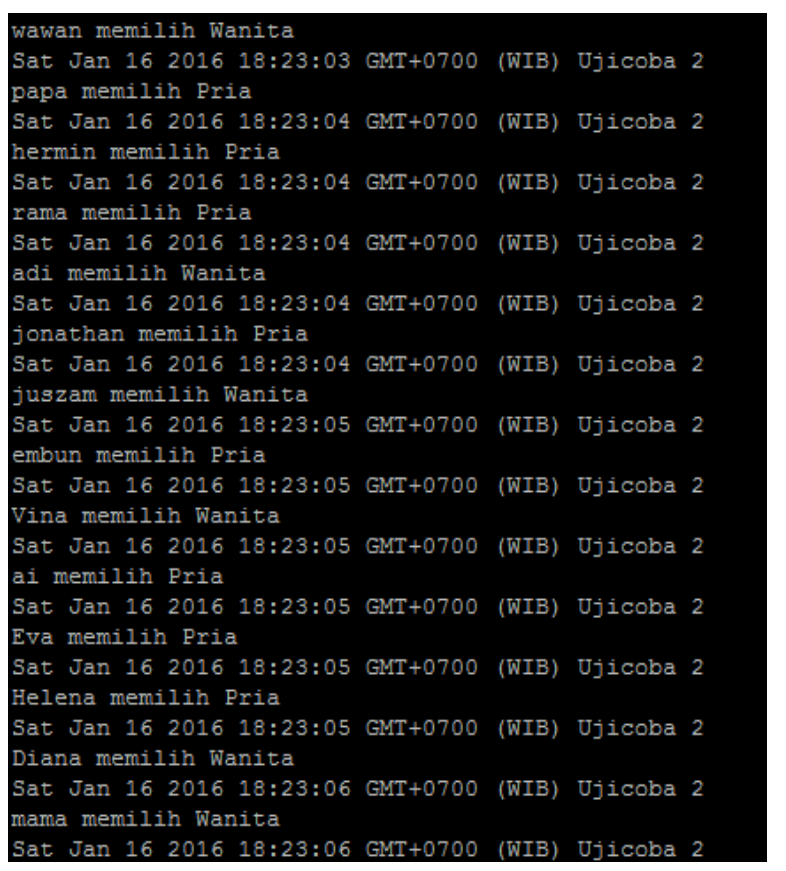

Gambar 17. Screenshot Log Server

\section{KESIMPULAN}

Dari hasil pembuatan audience response system dan pengimplementasian Node.js pada aplikasi GampangPoll dapat diambil beberapa kesimpulan antara lain:

- Sistem dapat melakukan vote secara real-time dengan menggunakan Socket.IO.

- Berdasarkan hasil ujicoba, diketahui tingkat reliabilitas sistem adalah $93 \%$ bergantung pada tinggi rendahnya komunikasi data dan banyaknya device yang terhubung pada jaringan wifi yang digunakan.

- Jaringan wifi pribadi atau closed network dengan modem router digunakan untuk dapat memperoleh hasil terbaik.

- Tidak disarankan untuk menggunakan wifi tethering dari smartphone android dikarenakan batasan maksimum user yang hanya berjumlah $5-8$.

\section{DAFTAR PUSTAKA}

[1] Android Architecture, ND, URI = http://www. tutorialspoint.com/android/android_architecture. $\mathrm{htm}$

[2] Chodorow, Kristina. 2013. MongoDB: The Definitive Guide. Retrieved Januari 16, 2016, from: usuaris.tinet.cat/bertolin/pdfs/mongodb_ the_definitive_guide.pdf

[3] Express.js Website. http://expressjs.com. Retrieved Januari 10, 2015.

[4] Green, Adams. 2013. Single-User Twitter OAuth Programming. Retrieved Januari 16, 2016. From 140dev.com/download/single-user-oauth.pdf

[5] Laili, N. 2009. Audience Response Systems Sebagai Alternatif Media Pembelajaran Interaktif Di Universitas.ND, URI = jurnal.fmipa. unila.ac.id/index.php/sains/article/download/218 .pdf

[6] Materializecss Website. http://materializecss. com. Retrieved Januari 10, 2015.

[7] Myer, Thomas. 2012. Beginning PhoneGap. Retrieved Januari 16, 201, from: https://www. ebooks-it.net/ebook/beginning-phonegap-1

[8] Nguyen, Don. 2012. Jump Start Node.js. Retrieved 26 October, 2014, from http://it-ebooks. info/book/2246/

[9] Lerner, M. R. 2011. At the Forge - NodeJS. Retrieved Januari 22, 2016, from: http://www. linuxjournal.com/article/11014.

[10] Zhangling, Y., Mao, D. A Real-Time Group Communication Architecture Based on Web Socket. Retrieved Januari 22, 2016, from: http://www.ijcce.org/papers/100-T0063.pdf 